\title{
PENERAPAN MODEL PEMBELAJARAN COOPERATIVE LEARNING TIPE STUDENT TEAM ACHIEVEMENT DIVISIONS DALAM UPAYA MENINGKATKAN HASIL BELAJAR SISWA
}

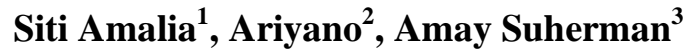 \\ Universitas Pendidikan Indonesia \\ Jl. Dr. Setiabudi No. 229 Bandung 40154 \\ sitiamaliaxd@gmail.com
}

\begin{abstract}
ABSTRAK
Tujuan penelitian ini untuk mengetahui pengaruh peningkatan hasil belajar yang dihasilkan dengan menerapkan model student team achievement division. Metode ini diterapkan pada mata pelajaran mekanika teknik dan elemen mesin Metode yang digunakan yaitu kuasi eksperimen dengan pendekatan kuantitatif dengan menjadikannya treatment untuk kelas eksperimen dan model pembelajaran konvensional untuk kelas kontrol. Pre test dilakukan sebelum kegiatan treatment dan post test dilakukan setelahnya. Maka nilai $N$-Gain yang didapatkan dari perhitungan skor pre test dan post test dijadikan data untuk uji hipotesis. Pengujian hipotesis menggunakan uji t dua arah. Hasil $N$-Gain kelas kontrol sebesar 56,27 sedangkan untuk kelas eksperimen nilai $N$-Gain sebesar 68,38. Hasil uji hipotesis menunjukkan nilai thitung sebesar 3,734 dan lebih besar dari $\mathrm{t}_{\text {tabel }}$ dengan derajat kebebasan $\mathrm{dk}=58$ yaitu bernilai 2,00. Hal ini menunjukkan penolakan $\mathrm{H} 0 \mathrm{dan}$ penerimaan hipotesis alternatif yaitu terdapat pengaruh penerapan model pembelajaran student team achievement division terhadap peningkatan hasil belajar.
\end{abstract}

Kata kunci: pembelajaran kooperatif, mekanika teknik, elemen mesin, hasil belajar.

\section{PENDAHULUAN}

Hasil observasi yang dilakukan di SMKN 2 Bandung pada pembelajaran mekanika teknik dan elemen mesin, pembelajaran masih berpusat pada guru sebagai pusat pembelajaran. Selama proses pembelajaran siswa kurang aktif dan hanya menerima materi dari guru yang merupakan ranah kognitif, sehingga ranah psikomotor dan afektif tidak dilibatkan dalam proses pembelajaran. Terlihat dari hasil belajar siswa pada mata pelajaran mekanika teknik dan elemen mesin (tiga tahun terakhir).

Hasil wawancara dengan guru pengampu mata pelajaran. Perolehan nilai yang terdapat dalam tabel adalah nilai murni sebelum dilakukan reward dan berbagai penambahan lainnya. Hasil nilai ini pun adalah dari pembelajaran yang biasa dilakukan yaitu dengan model konvensional metode ceramah. Berdasarkan hasil tersebut mengindikasikan kurangnya pemahaman konsep mekanika apabila dalam pembelajaran selalu bergantung kepada penjelasan guru. Aktivitas belajar di kelas siswa menjadi pasif dan berakibat pada kurangnya motivasi belajar.

Rumusan masalah dalam penelitian ini adalah apakah melalui penerapan model pembelajaran cooperative learning tipe student team achievement division (STAD)

\footnotetext{
${ }^{1}$ Mahasiswa Departemen Pendidikan Teknik Mesin FPTK, UPI

${ }^{2}$ Dosen Departemen Pendidikan Teknik Mesin FPTK, UPI

${ }^{3}$ Dosen Departemen Pendidikan Teknik Mesin FPTK, UPI
} 
terdapat pengaruh terhadap peningkatan hasil belajar dan aktivitas belajar siswa dalam pembelajaran mekanika teknik dan elemen mesin kompetensi sambungan di SMKN 2 Bandung. Tujuan penelitian ini adalah untuk mengetahui apakah terdapat pengaruh penerapan model pembelajaran cooperative learning tipe student team achievement division (STAD) terhadap peningkatan hasil belajar siswa dalam pembelajaran mekanika teknik dan elemen mesin kompetensi sambungan di SMKN 2 Bandung. Untuk mngetahui apakah melalui penerapan model pembelajaran cooperative learning tipe student team achievement division (STAD) membuat aktivitas belajar siswa lebih aktif dalam pembelajaran mekanika teknik dan elemen mesin kompetensi sambungan di SMKN 2 Bandung.

Pengajaran mekanika teknik dan elemen mesin terutama dalam hal penggunaan model pembelajaran. Selain itu, diharapkan akan dapat melengkapi kajian mengenai teknik pelaksanaan, peran, dan manfaat model pembelajaran cooperative learning tipe student team achievement division (STAD). Belajar adalah suatu proses perubahan tingkah laku individu yang terjadi akibat interaksi dengan lingkungan. Pembelajaran, merupakan hal membelajarkan yang artinya mengacu ke segala daya upaya bagaimana membuat seseorang belajar, bagaimana menghasilkan terjadinya peristiwa belajar di dalam diri orang tersebut. Komponen dalam proses pembelajaran memegang peranan yang sangat penting salah satunya adalah guru. Guru sangat penting untuk memahami teori belajar dan pembelajaran, agar dapat memberikan bimbingan kepada anak didik sebaik-baiknya. (Lufri, 2007).

Aktivitas artinya kegiatan atau keaktifan. Belajar adalah berusaha memperoleh kepandaian atau ilmu . Kedua arti di atas jika digabungkan akan mempunyai pengertian aktivitas belajar adalah kegiatan atau keaktifan seseorang dalam berusaha untuk memperoleh kepandaian atau ilmu. Hasil belajar merupakan hal yang dapat dipandang dari dua sisi yaitu sisi siswa dan dari sisi guru (Dimyati dan Mudjiono, 2006). Siswi siswa, hasil belajar merupakan tingkat perkembangan mental yang lebih baik bila dibandingkan pada saat sebelum belajar. Tingkat perkembangan mental tersebut terwujud pada jenisjenis ranah kognitif, afektif, dan psikomotor. Sedangkan dari sisi guru, hasil belajar merupakan saat terselesaikannya bahan pelajaran.

Model pembelajaran pada dasarnya merupakan bentuk pembelajaran yang tergambar dari awal sampai akhir yang disajikan secara khas oleh guru. Dengan kata lain, model pembelajaran merupakan bungkus atau bingkai dari penerapan suatu pendekatan, metode, dan teknik pembelajaran. Tentunya model pembelajaran harus dipersiapkan dan dibuat 
sebuah inovasi agar pembelajaran yang akan dilaksanakan bisa mencapai tujuan pembelajaran. Ada keuntungan positif dalam sikap berkooperatif dan prestasi belajar (Vaughan, 2002). Sikap kooperatif dalam pembelajaran biasanya dilaksanakan dalam model pembelajaran kooperatif atau cooperative learning, sehingga dalam penelitian kali ini peneliti akan menerapkan model pembelajaran kooperatif sebagai upaya untuk meningkatkan hasil belajar. Pembelajaran kooperatif merupakan model pembelajaran dengan menggunakan sistem pengelompokkan/tim kecil, yaitu antara empat sampai enam orang yang mempunyai latar belakang berbeda (heterogen) (Sanjaya, 2010). Setiap kelompok akan memperoleh penghargaan (reward), jika kelompok mampu menunjukkan prestasi yang dipersyaratkan. Dengan demikian, setiap kelompok akan mempunyai ketergantungan positif.

Mengembangkan suatu strategi untuk meningkatkan motivasi siswa melalui kerja sama dalam kelompok dan kompetisi antarkelompok (Eggen and Kauchak, 2012). Dalam STAD, sebuah kelompok beranggotakan sekitar lima orang dari kedua jenis kelamin, berbagai tingkat kemampuan, dan etnis. Pengajar akan membuat individual learning expectation (ekspektasi belajar individu) berdasarkan kemampuan masing-masing individu. Ekspektasi belajar individu ini menggambarkan kemampuan rata-rata dari individu tersebut. Model STAD dalam hal ini mempunyai kontribusi sebagai komponen proses pembelajaran. Di mana sebuah model yang diterapkan pada pembelajaran sangat diharapkan dapat memaksimalkan proses pembelajaran agar hasil dari pembelajaran berupa ketercapaian pemahaman dan prestasi belajar dapat dicapai dengan baik oleh peserta didik.

Mekanika teknik dan elemen mesin termasuk ke dalam kelompok C2 dalam struktur kurikulum 2013 dan merupakan salah satu mata pelajaran SMK dasar di jurusan Teknik Mesin. Pelajaran mekanika teknik dan elemen mesin ini tentunya mata pelajaran yang penting bagi siswa kelas $\mathrm{X}$ semester 1 dan semester 2 jurusan Teknik Mesin untuk bisa melanjutkan materi di jenjang berikutnya. Terdiri atas pemecahan masalah dari masingmasing kompetensi yang diharuskan dicapai oleh siswa meliputi prinsip dasar keseimbangan struktur dan kekuatan serta komponen utama pada mesin. Alokasi waktu pada tiap pertemuan dilaksanakan selama 2 jam pelajaran ( 2 x 40 menit).

Karakteristik model pembelajaran kooperatif tipe STAD yang mengutamakan pembelajaran berorientasi pada siswa. Fokus dalam hal kerja sama dalam pemecahan masalah, serta peningkatan motivasi untuk mencapai aktualisasi diri dinilai sesuai untuk digunakan dalam proses pembelajaran mata pelajaran mekanika teknik dan elemen mesin. 
Pembelajaran dengan model pembelajaran kooperatif tipe STAD merupakan suatu strategi pembelajaran berbasis konstruktivisme yang memberikan kesempatan kepada siswa dalam kelompoknya untuk membentuk pengetahuannya sendiri. Memberikan pendampingan kepada siswa dalam membentuk pengetahuannya sendiri. Siswa akan lebih aktif dan mudah memahami dan menemukan konsep mekanika teknik dan elemen mesin yang dihadapi dengan temannya. Siswa tidak menghafal konsep saja melainkan dapat menerapkan konsep tersebut untuk menyelesaikan persoalan yang dihadapinya di dunia kerja kemudian hari.

\section{METODE PENELITIAN}

Metode yang digunakan dalam penelitian ini adalah pendekatan kuantitatif. Penelitian kuantitatif adalah suatu proses menemukan pengetahuan yang menggunakan data berupa angka sebagai alat menemukan keterangan yang ingin kita ketahui. Mengungkapkan terdapat beberapa bentuk desain eksperimen yang dapat digunakan dalam penelitian, yaitu pre-experimental design, true experimental design dan quasi experimental design. Terdapat beberapa desain dalam quasi experimental design, dan peneliti menggunakan desain nonequivalent groups pre test post test karena dinilai sesuai dengan penelitian yang akan dijalankan. Desain ini terdapat kelompok eksperimen dan kelompok kontrol yang subjeknya dipilih secara random dan nantinya akan diobservasi 2 kali (pretest dan post-test) setelah salah satu kelompoknya (dalam hal ini kelompok eksperimen) diberi sebuah treatment untuk membuktikan sebuah perbedaan.

Studi pendahuluan dilakukan untuk memperoleh gambaran mengenai kondisi pembelajaran yang terjadi di SMKN 2 Bandung, juga gambaran mengenai model pembelajaran koperatif tipe STAD dalam penerapan pada mata pelajaran mekanika teknik dan elemen mesin. Studi pendahuluan dilakukan dengan melakukan observasi juga wawancara dengan guru pengampu mata pelajaran yang bersangkutan. Pre test juga dilakukan masing-masing kelas kontrol maupun kelas eksperimen. Untuk mengukur tingkat pemahaman awal peserta didik terhadap materi kompetensi dasar pada dua kelas yang dijadikan sampel sebelum dilakukan treatment, agar penelitian eksperimen ini bisa berangkat dari titik tolak yang sama. Sehingga hasil signifikan dari penelitian ini adalah pengaruh dari variabel eksperimen.

Pelaksanaan penelitian ini dilakukan di dalam proses belajar mengajar dan dalam beberapa tahapan. Dilakukan selama 2 kali pertemuan di masing-masing kelas dengan peneliti ikut serta dalam kegiatan pembelajaran sehingga bisa langsung didapatkan lembar 
observasi. Student team achievement division (STAD) sendiri terdiri dari beberapa tahapan. Pembelajaran yang telah dilakukan kemudian dilakukan pengukuran dengan memberikan post test untuk masing-masing kelas kontrol dan kelas eksperimen. Data tersebut kemudian diolah dengan analisis statistik untuk mengetahui hasil dari eksperimen yang telah dilakukan. Teknik analisis data yang digunakan adalah perhitungan skor rata-rata aktivitas pembelajaran di kelas juga pengujian hipotesis. Untuk menguji hipotesis digunakan uji $t$ di mana terdapat dua tahap yaitu deskripsi statistik data dan uji persyaratan analisis.

\section{HASIL PENELITIAN}

Hasil observasi lembar aktivitas siswa menunjukkan rata-rata aktivitas di masingmasing kelas terdapat perbedaan, yaitu kelas 11 dengan kategori cukup, kelas eksperimen 14,1 kategori aktif. Nilai rata-rata pre test yang di dapatkan di kedua kelas menunjukkan hasil nilai di bawah KKM yang relatif sama yaitu 29,51 di kelas TM 6 (kelas Kontrol) dan 31,89 di kelas TM 7 (kelas Eksperimen). Dengan nilai tertinggi di masing-masing kelas kontrol dan kelas eksperimen adalah 45 dan 40. Nilai terendah dikedua kelas penelitian adalah sama yaitu 20. Nilai rata-rata post test kelas kontrol adalah 69,19 sedangkan untuk kelas eksperimen adalah 78,1. Nilai hasil post test tersebut menunjukkan bahwa nilai ratarata kelas eksperimen yang diberikan treatment model pembelajaran STAD telah melewati nilai KKM yaitu sebesar 75 sedangkan kelas kontrol rata-rata nilai hasil belajar belum memenuhi nilai KKM.

Nilai $\mathrm{N}$-Gain pada kelas kontrol mempunyai rata-rata 0,5627 yang tersebar di 3 kategori $N$-Gain. Kategori $N$-Gain rendah terdapat 3 peserta didik, kategori sedang 23 peserta didik, kategori tinggi 5 peserta didik. $N$-Gain tertinggi diperoleh dengan nilai 81,81 dan terendah dengan nilai 23,07. $N$-Gain kelas eksperimen dengan rata-rata $N$-Gain nya sebesar 0,68. Sedangkan $N$-Gain kelas eksperimen memiliki $N$-Gain kategori sedang 15 peserta didik, dan kategori tinggi 14 peserta didik dengan rata-rata $N$-Gain 0,68.

Hasil uji normalitas pretest kelas kontrol dan eksperimen dan uji normalitas posttest kelas kontrol dan eksperimen semuanya normal. Pengujian normalitas dapat diketahui hasilnya bahwa apabila nilai signifikansi lebih besar dari 0,05 pada $(\mathrm{P}>0,05)$, maka berdistribusi normal, apabila nilai signifikansi lebih kecil dari 0,05 pada ( $\mathrm{P}<0,05)$, maka berdistribusi tidak normal. Hasil dari seluruh pre test maupun post test di masing-masing kelas terdistribusi normal. Nilai signifikansi nilai pre test adalah 0,276 juga nilai signifikansi nilai post test adalah 0,575. Di mana kedua angka signifikansi tersebut lebih 
besar dari pada 0,05 maka data kelas kontrol berdasarkan kelas eksperimen mempunyai varian yang sama atau homogen.

Hasil pengujian hipotesis bahwa besarnya $t_{\text {hitung }}$ untuk pengujian hipotesis sebesar 3,734. Kemudian nilai $t_{\text {hitung }}$ dikonsultasikan dengan nilai $t_{\text {tabel }}$ pada derajat kebebasan 58 $\left(\mathrm{dk}=\left(\mathrm{n}_{1}+\mathrm{n}_{2}\right)-2=58\right)$ pada taraf kepercayaan 95\% yaitu sebesar 2,00 di mana hal ini berarti nilai $\mathrm{t}_{\text {hitung }}$ lebih besar daripada $\mathrm{t}_{\text {tabel }}$. Hal ini menunjukkan bahwa $\mathrm{H}_{0}$ ditolak dan $\mathrm{H}_{\mathrm{i}}$ diterima. Artinya ada pengaruh penerapan model pembelajaran Cooperative Learning tipe STAD terhadap peningkatan hasil belajar siswa dalam pembelajaran mekanika teknik dan elemen mesin kompetensi sambungan.

\section{PEMBAHASAN}

Peningkatan hasil belajar dengan menerapkan model pembelajaran Cooperative Learning tipe STAD peserta didik dapat memperoleh pengetahuan lewat kerja sama kelompok. Hasil tersebut kemudian dipertanggung jawabkan oleh dirinya pada pemberian kuis. Sehingga sumbangsih nilai pribadi pada kelompok akan menentukan apakah kelompok mereka akan mendapatkan reward. Tentunya hal ini akan menambah motivasi peserta didik untuk lebih terpacu dalam memahami proses pembelajaran. Model pembelajaran Cooperative Learning tipe STAD membuat siswa lebih termotivasi hingga menaikan hasil belajar di kelas.

Model pembelajaran ini juga membuat aktivitas belajar di kelas eksperimen menjadi lebih aktif jika dibandingkan dengan kelas kontrol. Terlihat dari hasil observasi dan perhitungan aktivitas belajar peserta didik kelas eksperimen mempunyai angka 14,1 yang menjadikannya kategori aktif. Motivasi berprestasi mendorong seseorang berpacu dengan keunggulan serta mendorong seseorang untuk lebih berpartisipasi aktif dalam satu aktivitas (Firmansyah, 2009). Motivasi belajar dan aktivitas belajar peserta didik mempunyai pengaruh dalam prestasi belajar. Metode STAD memberikan tingkat yang lebih tinggi dari keterlibatan dalam proses pembelajaran sebagai dibandingkan dengan metode pengajaran yang biasa (Majoka dkk, 2010).

Peningkatan di kelas kontrol disebabkan berbagai faktor baik internal maupun eksternal. Ketika model pembelajaran konvensional diterapkan sebagai faktor eksternal untuk mencapai hasil belajar, tentu membawa pengaruh terhadap peningkatan pemahaman siswa pada materi setelah dilakukan pembelajaran meskipun dengan model pembelajaran konvensional. Kelemahan model ini adalah terlihat pada hasil observasi dimana aktivitas belajar yang terjadi dikelas kontrol termasuk kedalam kategori cukup aktif, artinya hanya 
sebagian peserta didik yang aktif dalam pembelajaran. Kelemahan dalam menerapkan model pembelajaran konvensional adalah siswa jadi lebih pasif dan guru akan kesulitan dalam mengetahui apakah siswa itu tertarik atau mengerti terhadap materi yang disampaikan (Djamarah dan Zain, 2009).

Pengujian hipotesis membuktikan bahwa terdapat pengaruh penerapan model pembelajaran Cooperative Learning Tipe STAD dalam upaya meningkatkan prestasi belajar mata pelajaran mekanika teknik. Terdapat peningkatan hasil belajar yang signifikan terhadap kelas yang diberikan treatment model pembelajaran tipe STAD. Hal ini di tunjukan dengan adanya perbedaan nilai $N$-Gain kelas kontrol dengan $N$-Gain kelas eksperimen. Kelas eksperimen memiliki $N$-Gain sebesar 68,38 dan kelas kontrol memiliki $N$-Gain sebesar 58,27.

Penerapan model pembelajaran kooperatif tipe STAD ini menuntut guru untuk menjalankan berbagai sintak dalam pembelajaran agar prestasi peserta didik dapat lebih optimal. Aktivitas belajar siswa di kelas yang mendapatkan treatment model ini masuk ke dalam kategori aktif di mana memang seharusnya aktivitas pembelajaran berlangsung. Ini membuktikan bahwa pada prosesnya model pembelajaran Cooperative Learning tipe STAD memang ikut serta menaikkan kategori aktivitas belajar yang terjadi di kelas selain dengan peningkatan hasil belajar. Berbeda dengan aktivitas pembelajaran di kelas kontrol di mana aktivitas cenderung cukup aktif atau berarti hanya sebagian peserta didik yang aktif dan sebagian lain masih pasif. Hal ini tentunya berdampak kepada hasil belajar siswa yang memang terbukti memiliki peningkatan yang lebih rendah dibandingkan dengan kelas eksperimen meskipun kedua nilai $\mathrm{N}$-Gain di kedua kelas sama-sama termasuk ke dalam kategori sedang.

Penerapan model pembelajaran Cooperative Learning tipe STAD mengharapkan adanya keseimbangan pencapaian kompetensi dengan sikap sosial anak di kelas yang dituntut agar bisa belajar dalam kelompok kecil. Materi yang diberikan adalah materi tentang sambungan las yang merupakan bagian dari materi C2 Mekanika teknik dan elemen mesin yang harus dikuasai oleh siswa teknik mesin, karena materi ini akan sering mereka temui baik di lingkungan masyarakat maupun di dunia kerja (Wina, 2011).

\section{KESIMPULAN}

Kesimpulan penelitian ini sebagai berikut: terdapat pengaruh penerapan model pembelajaran Cooperative Learning tipe Student Team Achievement Division terhadap 
peningkatan hasil belajar siswa. Penerapan pembelajaran Cooperative Learning tipe Student Team Achievement Division membuat aktivitas yang terjadi dikelas lebih aktif pada mata pelajaran mekanika teknik dan elemen mesin kompetensi sambungan.

\section{REFERENSI}

Dimyati, dan Mudjiono. (2006). Belajar dan pembelajaran. Jakarta: PT. Rineka Cipta.

Djamarah, S. B \& Zain, A. (2006). Strategi belajar mengajar. Jakarta: PT. Rineka Cipta.

Eggen, P. dan Kauchak, D. (2012). Strategi dan model pembelajaran. Jakarta: PT Indeks.

Firmansyah, H. (2009). Hubungan motivasi berprestasi dengan hasil belajar pendidikan jasmani. Jurnal Pendidikan Jasmani Indonesia, 6 (1), hlm. 30-33.

Lufri. (2007). Strategi pembelajaran biologi. Padang: UNP Press.

Majoka, I. M. dkk. (2010). Student Team Achievement Division (STAD) as an active learning strategy: Empirical Evidence From Mathematics Classroom. Journal of Education and Sociology, 2 (12), hlm, 16-20.

Wina, S. (2011). Strategi pembelajaran berorientasi standar proses pendidikan. Jakarta: Penerbit Kencana.

Vaughan, W. (2002). Effects of cooperative learning on achievement and attitude among students of color. The Journal of Educational Research, 95 (6), hlm. 359-364. 